\title{
Understanding ASEAN Peace Preservation Role in the Korean Peninsula
}

\author{
Rangga Amalul Akhli \\ Indonesia Defence University
}

\begin{abstract}
Since its inception in 1967, ASEAN has an important role to establish regional security and peacebuilding in Southeast Asia. Realizing that peace preservation needs to be extended to its northern neighbour, ASEAN initiated mechanisms that would enable it to play greater role in Korean peninsula. However, the association's effort to preserve peace in the region is inseparable from criticism which stated that this association was not effective to reconcile the two-Koreas. Among the pessimism of ASEAN's role in Korean Peninsula, this paper is presented to respond that argument. Furthermore, by using the constructivism paradigm, this paper argues that ASEAN approach believes in norms building to address security challenges in Korean peninsula uncovers space for peace preservation in other ways amidst other options and mechanisms which in fact last briefly and exacerbate hostility. To conclude, the approach has been useful for several reasons, such as maintaining the continuity of the multilateralism ties with North Korea and being an important actor that can be trusted by two Koreas amidst of the big powers' influences.
\end{abstract}

Keywords: ASEAN, Korea Peninsula, Peace Preservation

Sejak pertama kali dibentuk pada tahun 1967, ASEAN berperan penting dalam membangun keamanan dan perdamaian di kawasan Asia Tenggara. Upaya tersebut terus berlanjut hingga saat ini. Menyadari bahwa pemeliharaan pedamaian perlu diperluas pada kawasan di utaranya, ASEAN menggagas mekanisme-mekanisme yang memungkinkan ASEAN untuk berperan menjaga perdamaian di semenanjung Korea. Tetapi, kiprahnya dalam menjaga perdamaian di kawasan tidak terlepas dari kritikan yang menyatakan bahwa organisasi ini tidak efektif dalam mendamaikan kedua Korea. Di tengah pesimisme peran ASEAN di Semenanjung Korea, tulisan ini dibuat untuk merespon argumen tersebut. Tulisan ini bergargumen bahwa pendekatan ASEAN yang percaya pada pembangunan norma dalam mengatasi konflik keamanan di semenanjung Korea justru membuka ruang bagi pemeliharaan perdamaian dengan cara lain di tengah opsi-opsi dan mekanisme-mekanisme yang seringkali berakhir singkat dan memperuncing permusuhan. Tulisan ini menyimpulkan bahwa pendekatan tersebut telah berguna bagi beberapa hal, seperti menjaga kesinambungan ikatan multilateralisme dengan Korea Utara dan sebagai aktor penting yang dapat dipercaya oleh kedua Korea di tengah pusaran pengaruh yang melibatkan pertarungan kekuatan-kekuatan besar.

Kata Kunci: ASEAN, Semenanjung Korea, Pemeliharaan Perdamaian 


\section{Introduction}

No one denies that North Korea's aspiration to be a nuclear power remain as one of the main regional security challenges. More importantly, this issue is not merely a regional concern, but also international concern, due to its deadly effect and concerted global efforts to control North Korean nuclear programs under nonproliferation treaty. Hence, developing nuclear arsenal is considered a violation of the treaty and a threat to global peace order. Consequently, international community should urge for denuclearization, either by softer methods, such as diplomatic actions and economic assistances, or by harder methods like imposing economic sanctions and pre-emptive military strikes. Here, North Korea is experiencing the same pressure. The state was a party of NPT before its withdrawal in 2003. Since then, North Korea has conducted six times nuclear test and become the only nation to test the weapon in this century. Among international calls for stripping down of its nuclear, ASEAN has its own manner to handle the North Korean nuclear and preserve the peace in the Korean Peninsula by relying on norms building such as the TAC and the SEANFWZ and its consultative forum ARF, issuing that it should move in a comfortable manner for all participants.

In spite of the efforts, ASEAN has been criticized for a number of reasons. For example, Yuzawa describes that the ASEAN-led mechanism, namely ARF, as a mere talk shop that lacks of meaningful progress (Yuzawa 2005). Yuzawa also highlights the permission of North Korea involvement in the ARF as a bad idea that causes ineffectiveness of the forum to reach any significant steps. In addition, Kim Jae-kyoung also stated that ARF is likely to have improvement in rhetoric, but little progress in action (Kim 2007). In this sense, the uneasy feelings are likely coming from big expectations towards peace development in the region, particularly since ARF is the only official multilateral security platform that draws North Korea nuclear participation in it. Here, the author does understand those contra-arguments; however, I argue that those arguments cannot determine whether ASEAN has succeeded or failed on resolving the conflict, because ASEAN actually conducts a longterm effort. In this regard, author argues that ASEAN facilitates more acceptable process of interactions amid the stalemate of talks to bring North Korea's participation. The focal point of this foundation is to share understanding. The previous international efforts to disarm the North Korea nuclear were unsuccessful due to the ruled out of mutual understanding and the North cannot fully trust the other parties. In spite of its support for the non-proliferation, ASEAN neither oust nor hostile the North, since it contradicts with the shared values. Against this backdrop, this piece will discuss several points. First, it discusses the main theoretical background. Second, it explains ASEAN's modality to preserve peace. Third, it explicates the security and peace challenges in 
the Korean Peninsula. Fourth, it discusses how ASEAN handles peace on the Peninsula.

\section{Theoretical Argument}

Of the most part of the world, ASEAN paves the way of managing regional peace order by actively fostering dialogues and interactions on the one hand, and preventing major war from escalating on the other hand. ASEAN method that trusts in norms building, which is commonly understood as shared expectations about appropriate or legitimate behaviours with particular identity (McDonald 2008), is important to mitigate the zero-sum game model in Korean Peninsula. This approach can be understood through the lens of constructivism in International Relations theory.

Constructivism rises along with critique of rationalism perspectives in International Relations. It depicts the ontology of international relations in the social ontology contexts, emphasizing the importance of normative meaning and process of interaction, while does not reject the wholesale of the rationalism regarding the structure. For rationalists, such as neoliberalists and neorealists, structure is understood as a function of competition and the distribution of material capabilities. In this view, structure constrains the action of states, so rational act is guided to produce an outcome that maximize the power or interest of individual unit. Meanwhile, constructivist believes that even though material factors play a role, but focus should be placed on norms and shared understanding of legitimate behaviour (Fierke 2013). The logic of constructivist is guided by the logic of appropriateness. According to this view, rational is about legitimacy that defined by shared values and norms within social structures or institution rather than purely individual states (March and Olson 2009). Hence, based on the logic, states become social through acquiring and fulfilling an institutional identity. In this respect, norms not only constrain, but also constitute the identity of the actors (Fierke 2013).

In addition, the theory emphasizes that anarchy of international system does not always lead to war, rather it depends on how states construct the others either as enemy or friend. Here, the agents and the process of interaction become essential parts to socially construct the nature of world politics, leading constructivists to conclude that change is always possible.

According to the outlook above, the author argues that ASEAN tries to construct the participants in the mechanism, particularly those involve in peace and security development in Korean Peninsula to take steps in accordance to the norms it upholds all this time. The forum, like ARF, invites two-Koreas or other powers to pave the way for other possibilities 
other than political powers, hoping that the interactions can raise better understanding and change behaviour from animosity to goodwill.

ASEAN understands that conflicts in Korean Peninsula someday can reach the worst level should the zero-sum game still rule. It can also affect the stability in region, particularly if it involves nuclear weapons. Among the sanctions imposed to the North, ASEAN as a regional grouping, though disagree with the development of North Korean nuclear, does not try to isolate the North. Instead, it keeps inviting the North as a participant due to the importance of confidence building measures. Though ASEAN is unable to disarm the North, its contributions in managing peace in Korean Peninsula and striving for more responsible North Korea through its regular mechanisms cannot be said as a failure. Rather, it is an ongoing process.

\section{ASEAN Modality for Peace Preservation}

Established in 1994, ARF marked another historical progress for ASEAN regional peace and security development through intensification of cooperative ties with external actors. It is not only thriving to maintain and preserve the peace construction in Southeast Asia alone, but also in broader regions, including Korean Peninsula. The aim is to design further constructive dialogue and consultation on political and security issues of common interest and concern, as well as make significant contributions towards confidence-building and preventive diplomacy in Asia Pacific region (ASEAN Regional Forum 1994).

Dating back to ASEAN establishment in 1967, it has originally participated in various tension reduced efforts. One should remember about how the association, in the first decade of its establishment, had shifted bilateral tensions between state members by making sense of necessary cooperation and commitment-sharing for regional peace and prosperity. In addition, it also shifted the chaotic ASEAN-Vietnam relation which was started by peace offensive in 1970s and contributed to the comprehensive peace agreement in Cambodia through the creation of UNTAC (Weatherbee 2009). Therefore, to settle tensions among states and transform it into more peaceful relations, ASEAN have always used diplomatic effort, economic cooperation, and the ASEAN Ways as its norm, rather than conducting military intervention and violating states sovereignty.

In author's understanding, there are three fundamental instruments which correlate with peace preservation in ASEAN, namely ZOPFAN (Zone of Peace, Freedom and Neutrality), TAC (Treaty of Amity and Cooperation), and SEANFWZ (Southeast Asian Nations Free Weapon Zone). 
The Zone of Peace, Freedom, and Neutrality Declaration issued on November 27, 1971 in Malaysia, four years after the Bangkok Declaration. It proclaimed that regional groupings must be neutral amidst big power politics. According to the declaration, neutrality means states shall maintain their impartiality and refrain from both direct and indirect involvement in ideology, politics, economics, army, or any forms of conflict. It shall not interfere with the contestation of power outside the zone and likewise, external power shall not interfere in the domestic or regional affairs. It is also regarded to end an era of regional sphere of influence where small states used as pawns in the big power conflict (M.C Abad 2000).

Four years later, following ZOFPAN guidelines, the Treaty of Amity and Cooperation (TAC) was signed in Indonesia. The TAC is a legally binding code of conduct for inter-state relations in Southeast Asia to establish a fundamental principle and become ASEAN's trademark of framework (ASEAN Regional Forum 2013). It stipulates that the relationship between High Contracting Parties is guided by following fundamental principles: (1) mutual respect for independence, sovereignty, equality, territorial integrity, and national identity of all nations; (2) right of every state to be free from external interference, subversion or coercion; (3) non-interference in the internal affairs of one another; (4) settlement of differences or disputes by peaceful means; (5) renunciation of the threat or use of force; and (6) effective cooperation among themselves.

Another modality is the Treaty of Southeast Asia Nuclear Weapon Free Zone (SEANFWZ) which was signed in Bangkok on December 1995. This treaty reflects and demonstrates ASEAN's effort to support global nonproliferation regime (ASEAN Regional Forum 2013). Under this treaty, the signatories agree to: (1) not to develop, manufacture, acquire, possess or have control over nuclear weapons; nuclear weapon stations; test or use nuclear weapons anywhere inside or outside the treaty zone; (2) not to take any action to assist or encourage the manufacture or acquisition of any nuclear explosive device by any state; (3) not to provide source or special fissionable materials or equipment to any NonNuclear Weapon State (NNWS), or any Nuclear Weapon State (NWS) unless subject to safeguards agreements with the International Atomic Energy Agency (IAEA); (4) to prevent stationing and testing any nuclearexplosive device within the territory of state parties; and (5) not to dump radioactive wastes and other radioactive matters at sea anywhere within the zone and to prevent the dumping of radioactive wastes and other radioactive matters by anyone in the territorial sea of the state parties.

\section{The Peace and Security Challenges in Korean Peninsula}

Korean Peninsula security cannot be discussed without paying attention to struggle of great power politics there. Since the end of World War II, 
the peninsula is divided into two, the North and the South that backed by the eastern allies and the western allies respectively. Korean War technically ended in 1953, yet it had been concluded with formal peace treaty yet. The signing of defence treaty between US and South Korea, in North Korea's perspective, had worsened the situation, particularly since United States stationed nuclear weapons in South Korea in 1958. In response to that, North Korea reacted by signing mutual defence treaties both with USSR and China to assure balance of power in the peninsula and letting them to get deeper into cold war competition (Jae-bong 2009).

However, instead of relying on the eastern allies' nuclear umbrella, Kim Il-sung began to seek nuclear power for North Korea. He asked Soviet (1963) and China (1964) to develop nuclear weapons, even though its allies firstly rebuffed the idea later Soviet agreed to help building peaceful nuclear program by training nuclear scientist (Jae-bong 2009). While peaceful program started, the search for such weapon remained contested. There are several reasons why Kim Il-sung pursued nuclear power. It came from the fear to become prey of United State and its allies and possible impact if the North was overly dependent on the Soviet Union, particularly after Cuba Missile Crisis and armed clash with China along Sino-North Korea border in 1969. It worsened the trust between these communist countries; hence, pursuing nuclear program was the best choice (Sulaiman 2017).

To prevent North Korea becoming a nuclear state, international community pushed the state to denuclearize. In September 1991, United States initiated to withdraw nuclear weapon from North Korea and making South Korean president, Roh Tae-woo, proclaimed that South Korea was free from nuclear weapons. As a result, both parties agreed to sign the Joint Declaration on denuclearization of the Korean Peninsula and promised not to test, manufacture, produce, receive, possess, store, deploy and use nuclear weapons. North Korea also signed IAEA safeguard agreement in 1992. Under the term of agreement, IAEA was allowed to investigate North Korea nuclear site. However, while IAEA requested the access to the suspect the sites, North Korea denied the allegation about having them as military sites. This was then responded by UNSC urging that North Korea should cooperate to implement the 1991 North South Denuclearization Accord in order to lift the sanctions (Cordesman 1996).

In response to North Korea's unwillingness to receive IAEA inspection, Jimmy Carter, United States President, visited North Korea in June 1994 to discuss the possibility of denuclearization. This visit resulted in an agreed framework on October that year in which North Korea pledged to dismantle and freeze its nuclear weapon programs in return of some economic assistances. Nevertheless, this framework did not satisfy both parties. North's dissatisfaction was caused by postponement of light- 
water reactors; while the US was dissatisfied by the postponement of safeguards inspections, causing their relations to take a bad turn (Cordesman 2016).

North Korea continued developing their nuclear programs despite the ongoing pressures. In 2002, uranium enrichment program marked another chapter of nuclear weapon proliferation in Korean Peninsula. North Korea refused to clarify on what was happening and accused IAEA to be in favour of the US' interest. As a result, a year later, North Korea announced its withdrawal from the NPT. The move subsequently implied other sanctions for North Korea. To halt the situation from deteriorating, Six Party Talks, consisted of North Korea, South Korea, Japan, United States, China, Russia, were held from 2003 to 2007; yet, it did not reach any significant steps towards full denuclearization of Korean Peninsula. The main problem of the talks is the trust building. Instead of fostering the amity, the talks were more focused on making another party to comply to ones' demands. North Korea itself is insecure about its survivability and dignity, due to the lack of trust building during the negotiation. This pattern consequently contributed to six nuclear tests by the North Korea.

\section{Engaging Korean Peninsula}

ASEAN has enjoyed security cooperation with both Koreas in various ways. With the Republic of Korea (ROK), the cooperation has been initiated since 1989 (ASEAN 2018). Since then, the relations have become broader and deeper, ranging from the creation of ASEAN-ROK Summit, ASEAN-ROK Dialogue and Senior Official Meetings, ASEAN Plus Three, the East Asia Summit, ARF, and ADMM Plus. Meanwhile, with the Democratic People's Republic of Korea (DPRK), ASEAN multilateral security cooperation can only occur through the ARF. DPRK joined the mechanism in mid-2000 or at the seventh meeting of ARF.

The participation of North Korea in the ARF was praised as a new hope for the Korean peninsula peace. Everyone was pleased with this decision. During this meeting North Korea agreed to open ties with Canada and New Zealand; normalized diplomatic relations with Japan; and desired to end the economic sanctions from US. Its involvement marked a great achievement for ASEAN. Surin Pitsuwan even stated that this is a big step forward for security and diplomacy in the region (Lee 2000).

Notwithstanding North Korea's participation, ASEAN remains proclaiming that proliferation of nuclear weapons as inacceptable. There was another multilateral forum besides ASEAN which is willing to end the proliferation nuclear weapon, namely Six Party Talks (Tan 2017). Unlike ASEAN, the Six Party Talks only effectively works for about five years from 2003-2007. The unresolved differences were the main reason 
behind it. Six Party Talks prefers "conditional engagement" which brings specific conditions and incentives affecting target states calculation about the cost and benefits. In other words, there are sticks and carrots in the negotiations. Meanwhile, ASEAN design called "unconditional engagement" by addressing conflict with a continuous dialogue. When a country breaks the norms, the others act to socialize it rather than employing coercive methods. ASEAN uses the ASEAN Ways such as non-interference in domestic affairs and consensus to deal with (Kim and Kang 2009). The ASEAN method is a bit promising in term of engaging North Korea than Six Party Talks. One important point is because North Korea could accept socialization style of ASEAN.

In 2017, Ri Jong-hyuk, the Deputy of North Korea's Supreme People Assembly, said that North Korea nuclear program was solely aimed at fighting US nukes and other country should not worry about attacks (Perper 2017). It occurred because North Korea felt insecure that United States would cause a collapse of the country. At the same time, North Korea will not aim its nuclear to Southeast Asian countries. This is why the constructivist said that anarchy is what states make of it; hence, states can construct each other, both as friends and enemies. The United States and North Korea need to really construct each other as a friend. The prerequisite for this construction requires confidence building measures, rather than posing stick and carrot strategy. Following that, ASEAN and ARF provided such confidence building measures. It makes a difference, yet it needs patience and passion to uphold it.

\section{Conclusion}

In fact, there are many parties hoping for North Korea denuclearization. The recent bilateral meetings, such as the US-DPRK or the ROK-DPRK initiated by Moon Jae-in the middle of 2018, deserve an appreciation. On the other hand, ASEAN plays another role in multilateral stage. North Korea participation in the ARF can be worth for preservation of peace for several reasons. First, it would be easier to preserve peace in the Korean Peninsula when it involves the North Korea as the active participant. Second, ASEAN has not successfully disarmed and resolved North Korea nuke; however, it has a role in avoiding the conflict to becoming a major war. Third, the ASEAN Way assures North Korea that the association will remain neutral. Fourth, ASEAN's introduction of its norms sets important point in the process of making North Korea as a responsible state. However, on top of all of these, it is acceptable that ASEAN plays a minor role. It will happen if the illegitimate behaviours are either openly or secretly acted out by the disputing parties. 


\section{References}

\section{Buku}

ASEAN Regional Forum, 2000. Chairman's Statement of the 7th Meeting of ASEAN Regional Forum. Jakarta: ASEAN Secretariat.

ASEAN Regional Forum, 2013. ASEAN Security Outlook 2013. Bandar Seri Begawan: ARF.

ASEAN, 2018. Overview of ASEAN-Republic of Korea Dialogue Relations. ASEAN.

Cordesman, A. H, 2016. North Korea Nuclear Forces and the Threat of Weapons of Mass Destruction in Northeast Asia. CSIS.

Fierke, K. M, 2013. "Constructivism”, in T. Dunne, M. Kurki, \& S. Smith, International Relations Theories: Discipline and Diversity ( $3^{\text {rd }}$ Edition). Oxford: Oxford University Press.

Kim, S. C., \& Kang, D. C., 2009. "Introduction: Engagement as a Viable Alternative", in S. C. Kim, \& D. C. Kang, Engagement with North Korea: A Viable Alternative. New York: State University of New York Press.

March, J. G. and Olson, J. P., 1989. Rediscovering Institutions. New York: Free Press.

McDonald, M. 2008. "Constructivism", in P. D. William, Security Studies: An Introduction. New York: Routledge.

Sulaiman, Y., 2017. "Why We Must Learn to Live with a Nuclear North Korea”. Global Asia: 12(3).

Weatherbee, D. E., 2009. International Relations in Southeast Asia Second Edition: The Stuggle for Autonomy. Plymouth: Rowman \& Littlefield Publishers, Inc.

\section{Artikel Ilmiah dan Laporan Resmi}

Lee, J.B, 2009. "US Deployment of Nuclear Weapons in 1950s South Korea \& North Korea Nuclear Development: Toward Denuclearization of the Korea Peninsula", The Asia Pacific Journal, 7(1).

M.C. Abad, J., 2000. "The Role of ASEAN in Security Multilateralism: ZOPFAN, TAC, SEANFWZ", in ASEAN Regional Forum Professional Development Programme. Bandar Seri Begawan: ARF.

Tan, M. H., 2017. "Multilateral Engagement of North Korea: An Assessment of the Six-Party Talks and the ASEAN Regional Forum". Asian Journal of Peacebuilding, 5(2): 307-324. 
Yuzawa, T. 2005. "Japan's changing conception of the ASEAN Regional Forum: from an optimistic liberal to a pessimistic realist perspective". The Pacific Review, 18(4): 463-497.

\section{Artikel Daring}

ASEAN Regional Forum, 1994. "Chairman's Statement of the 1st Meeting of the ASEAN Regional Forum" [online] in $\mathrm{http}$ ://aseanregionalforum.asean.org/component/content/articl e/3-content/public-library/131-chairmans-statement-of-the-1stmeeting-of-the-asean.html [accessed September 19, 2018].

Kim, J.K., 2017. "Should North Korea be ousted from ARF?" [online] in https://www.koreatimes.co.kr/www/biz/2017/o8/602_235212. html [accessed September 19, 2018].

Lee, C., 2000. "Analysis: North Korea offers new hope for Peace" [online] in https://www.upi.com/Archives/2000/07/30/Analysis-NorthKorea-offers-new-hope-for-peace/4473964929600/ [accessed September 19, 2018].

Perper, R., 2017. "North Korea says the US is its only nuclear target" [online] in https://www.businessinsider.sg/north-koreanuclear-targets-us-2017-11/?r=US\&IR=T [accessed September $28,2018]$. 